\title{
China's Back Door
}

\section{Michael Webster}

A resident in Hong Kong describes this British colony's trade in wild animals, as reported by a group of interested observers who kept a watch on markets and shops, coupled with the inadequate government statistics. The bulk of the trade is with China, but imports also include rhino horn and enormous quantities of ivory from Africa.

It is a proud boast of the Government of Hong Kong that it is among the world's top twenty trading nations; but in terms of the trade in wild animals it ranks even higher. Yet, while the total trade seems to be assessable to the last dollar, figures for the animal trade, although improving, are still vague. Since 1971 , as a parallel to Government statistics, some private individuals have been watching shops and markets in an attempt to work out approximately the volume of this trade and determine what species, if any, are likely to be endangered by it. The vast majority of imports come from the People's Republic of China, a country officially very conscious of the need to conserve wildlife, but one in which distances are so vast and communication still relatively so difficult that on wildlife conservation matters many provinces seem to act almost independently. The traffic in goods over the Hong Kong-China border is virtually uncontrolled; animals are imported in wooden crates, and no attempt is made by Customs to find out what is inside.

Two systems of assessing quantities exist. One requires all animal dealers to be licensed, which obliges them to keep a logbook of all animals - birds, mammals, reptiles and amphibians - that pass through their hands, with details of the species, date of sale or other disposal; but there is no means of checking the accuracy of the logs, and most dealers are incapable of correctly identifying any but the commonest species. The second requires dealers to obtain import permits and submit import declarations, but again, this system is wide open to abuse when no check can be made.

The animals are imported for a number of purposes. In Chinese tradition almost every bird, mammal, reptile or amphibian has certain medicinal or magical properties. Some customs, like the use of four particular pangolin scales to scare away ghosts, are obviously absurd, but others have a sound scientific basis. For example, snake and civet meats are eaten, as is dogmeat, to warm up the body in cold weather; since these meats are rich in aminoacids, at least one Western-trained doctor believes that they may indeed have the desired effect. China recently banned the export of pangolins, apparently because of a possibility that a cancer cure may be derived from some part of its body. Other species are imported simply because they are delicacies. Examples of these are deer (221 in 1974, 64 in 1975), pigs (99 and 202 respectively), wild ducks $(98,030$ and 27,062$)$, and geese. 'Delicacies' such as monkey's brain scooped from the living monkey and bear's paws roasted on the living bear are probably things of the past, though from time to time 
frozen bear's paws can still be obtained at the big Communist department stores.

There is also a trade in rarer species for re-export. The Chinese authorities, while reputed to have a long list, so far unconfirmed, of protected species, seem to place few restrictions on what may be exported. Early in 1976, black-necked cranes Grus nigricollis, apparently originating in China, reached Europe and the United States, probably via Hong Kong. On the other hand, in 1974 a hooded crane Grus monachus was shipped to Hong Kong from Canton in a consignment of common cranes Grus grus, but even before it arrived the dealer received a cable from Canton asking him to return it. One dealer was asked whether he could supply the scarce Lord Derby's parakeet Psittacula derbyana. The answer was yes, provided an order of 5000 could be placed: it would be uneconomic to mount a special expedition to the wilds of Yunnan for any less! In some provinces, annual quotas are set for certain species which may have a value as a natural resource, such as leopards. One province sets the annual limit for Panthera pardus at 3000.

In 1976, so that Britain could ratify the Washington Convention on International Trade in Endangered Species of Wild Fauna and Flora, Hong Kong rushed through the Animals and Plants (Protection of Endangered Species) Ordinance, which is full of anomalies. It does not precisely follow the Washington Convention, being in some ways an advance on it and in others a concession to Hong Kong business circles. While hawks and owls are fully protected (in 1975, 7075 hawks and 9486 owls were imported from China as food), the skins of all monitors Varanus are still permitted, because there is already a substantial trade in them. Live specimens and animal parts are listed separately, producing such curious anomalies as a ban on the skins of certain civets Viverrinae but no restriction on the live animals. Since they are normally imported as food, it appears that the offence begins as soon as the beast is killed.

The new legislation came into effect on November 51976 after a grace period of three months to enable dealers to get rid of their stocks. Enforcement, however, is still in the theoretical future. Virtually all fur dealers have stocks of leopard skins, some have tiger skins as well, and few, if any, have applied for licences under the new law. Strong public pressure on the Director of Agriculture and Fisheries, the enforcement authority, has been met with the anticipated shilly-shallying and buck-passing. However, at least two seizures of protected birds have been made, and there are signs that the Director, now that the bolt-holes have been closed, is preparing to take firmer action against the main Communist importers of wild birds and mammals. In fairness to the Director, it should be emphasised that law enforcement against Communist importers is not easy; for many years they have been treated with kid gloves by the Hong Kong Government, and naturally enough they continue to take advantage of the fact. In many ways the trade conducted by local Communist importers seems to conflict with Peking's official policies.

To the retail customer, little seems to have changed. He can still buy his wife a leopard-skin coat, and in status-conscious Hong Kong runs little risk of seeing it torn off her back. If he wants to drink owl soup, there is no difficulty in finding a street hawker who can sell him the owl, and hornbill casques and bird of paradise feathers are still obtainable. Ivory smuggled 


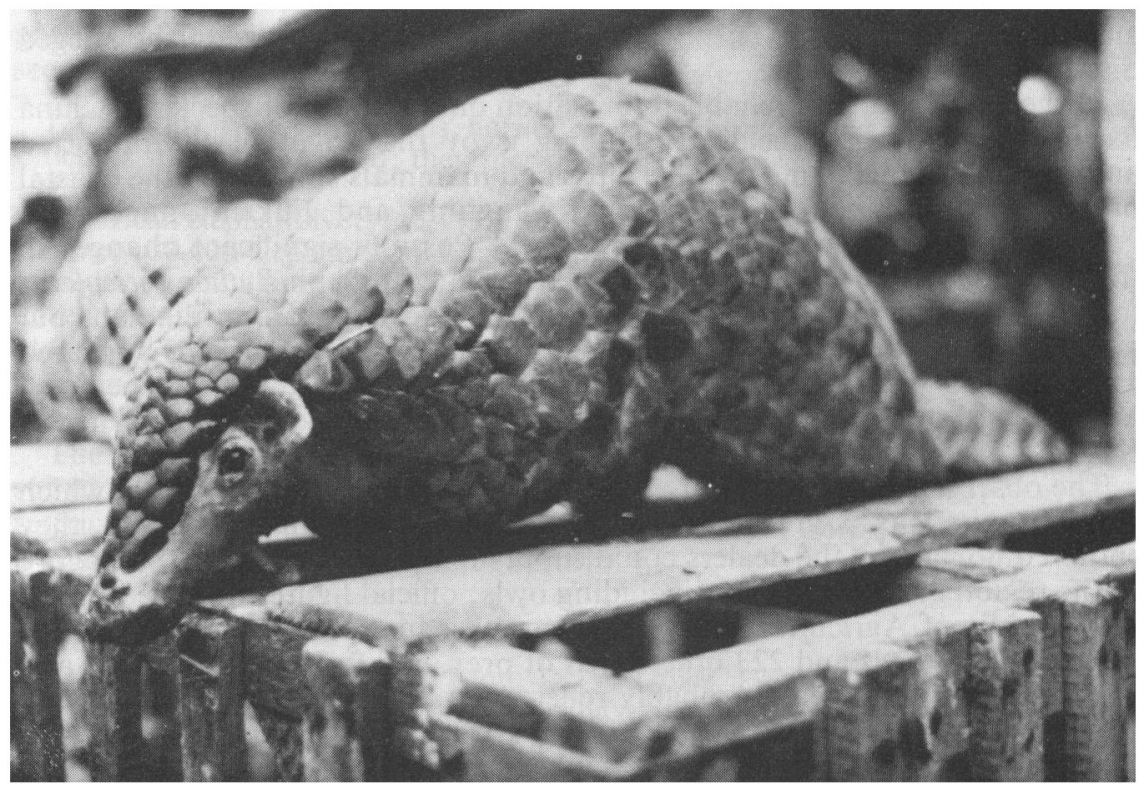

CHINESE PANGOLIN in Hong Kong shop Michael Webster

out of Africa finds a legal haven in Hong Kong, where the trade is so large (imports worth US\$ $15 \mathrm{~m}$ in 1975) that no Hong Kong Government is likely to do anything to hinder it, even though the export may be illegal in its country of origin. Many more animals are taken from the wild than reach the Hong Kong shops, and cruelty in the shops is normal. The bills of shrikes are snapped off with pliers, and those of owls wired shut; pangolins normally arrive in Hong Kong in a state of severe dehydration; snakes are skinned alive. But cruelty is usually so difficult to define that prosecutions or convictions are almost impossible to obtain. For example, the regulations on cage size merely say that it must be adequate, and there is nothing to prevent prey and predator being housed in adjacent cages. Delicate species, such as the smaller birds, must suffer immense losses between capture and final sale. We have seen many mammals with legs smashed in gin-traps, including the masked palm civet Paguma larvata, which the Government maintains, on the evidence of a 'traveller in China', is bred in captivity.

The scale of the trade must also be having an effect. When each village trapped civets and pangolins for its own use, it would probably only tap a small territory in the immediate vicinity, and, as stocks in the trapping territory were depleted, other animals would move in to fill the gap; but when all territory is trapped there is no surplus population anywhere to replace those caught. This applies particularly to pangolins. Their diet is restricted to the house termite Coptotermes formosanus, which means that they cannot exist in large numbers in any one place. Yet 2271 are known to have been imported into Hong Kong in 1972, 7004 in 1973, and 3426 in 1974, and these figures are undoubtedly conservative, as they only represent pangolins handled by the three main importers and reported by them to the Department of Agriculture 
and Fisheries. The figure fell to 10 in 1975 , doubtless because of the alleged discovery of a cancer cure.

In the absence of any reliable information on the status of species in China itself, one of the best means of judging is by the origin of the imported animals. Traditionally most of the birds and mammals come from the coastal provinces, chiefly the two nearest, Kwangtung and Fukien; ducks and geese come also from the Yangtse estuary. Possibly significant changes in the trade include the appearance of the reticulated python Python reticulatus for the first time in the winter of 1971-2, said to come from Yunnan, but never scientifically recorded in China. In the same winter, there appeared a number of yellow-bellied tits Parus venustulus, also alleged to be from Yunnan, although this coincided with an irruption of the species into Hong Kong.

The observers paid particular attention to the trade in birds of prey, which are recognised as a group in danger worldwide. Posing as buyers, they enquired how many the dealers could supply in a week, and got a total figure in the region of 10,000 a year, including owls; official figures obtained by the Department of Agriculture and Fisheries subsequent to this estimate were, for 1974, 2073 owls and 223 other birds of prey, and for 1975, 9486 owls and 7075 others. The increase probably reflects not an increase in the trade but greater accuracy in compiling records. Kestrels Falco tinnunculus made up about half the total. Other large numbers included several hundred black kites Milvus migrans, at least 1000 buzzards (chiefly Buteo buteo), 200-300 imperial eagles Aquila heliaca, and several hundred each of scops owls Otus scops, collared scops owls $O$. bakkamoena, eagle owls Bubo bubo, grass owls Tyto longimembris and short-eared owls Asio flammeus. Individual consignments of 300 hobbies Falco subbuteo, 300 sparrowhawks Accipiter spp. and 300 saker falcons Falco cherrug have been reported, the last named destined for falconers in Japan. The conditions under which these birds are kept are so bad that a high proportion are diseased, and few are fit enough to be of any use to falconers (except, probably, the sakers); they are generally destined for the pot.

Appeals from conservationists and anti-cruelty organisations have in the past fallen on deaf ears. The Government has been prepared to pass laws which look good but are unenforceable and not intended to be enforced. It is hoped that the new legislation, and the international focus which has been directed on the Hong Kong Government, and in particular the Department of Agriculture and Fisheries's appalling record in this field, will cause a long-needed improvement. The fundamental tool for law enforcement is statistics, and we are at last beginning to get statistics which, while certainly not accurate, are at least sufficiently near the truth to be used as a base for enforcement activities. However, the sufferer in this trade is China, not Hong Kong, and the final solution can only come from China. This will not happen without a determined effort on the part of the Hong Kong and British Governments, without whose pressure China is unlikely to act to restrain its merchant corporations.

Conservation organisations in Hong Kong are too weak to do more than make polite suggestions, which are as politely rejected or evaded, and so Hong Kong remains an exploiter of wildlife, irrespective of rarity. In the 
past, the following have been the main danger areas, and it remains to be seen whether the new legislation will effectively control them:

1. Cat skins, rhinoceros horns, hornbill casques, birds of paradise skins. The first item is still widely traded; the other three are now rarer;

2. Birds of prey;

3. African elephant ivory. In 1975, Hong Kong imported the ivory from approximately 30,000 elephants, and figures for the first three-quarters of 1976 already exceed the total figure for 1975 .

Live animals imported for food pass no health checks and are not slaughtered at official abattoirs. If the latter were made compulsory, it would help in assessing the scope of the trade, and the resulting complications would probably reduce its scale.

The wildlife trade cannot be completely stopped, but its impact could be substantially reduced if it were properly controlled and the number of species restricted. In Hong Kong one learns to recognise that unless the profit motive is respected, there is no hope for reform.

\section{Acknowledgments}

I would like to thank Miss P. Penn, Dr V. Lance, F.O.P. Hechtel, J. Llewellyn, K.T. Leung, and the many others who have provided material for this study. I would also like to thank the Agriculture and Fisheries Department for providing the official figures, which, though still inaccurate, go a long way towards substantiating criticisms that were previously based on unconfirmed estimates.

Michael Webster, 1/F, Block B, Mint Garden. 1-3 Cheong Ming Street, Happy Valley, Hong Kong.

\section{What Goes On}

The Director of the Jakarta Zoo received an unsolicited letter from the Director of the Ise-Shima Zoo of Kobe, Japan, A. Yoshikawa, who wanted to buy a bird of paradise (protected). He wrote, " . . it is suggested that the name of the item is to be specified just "magpie" instead of "Bird of Paradise" on all necessary documents and when shipped, the tail of the birds is to be pulled out and birds to be painted watercolour so that our sincere desire to get the birds can realize by any means'. Jakarta refused this 'monstrous request', but several weeks later received from the Ise-Shima Zoo a list of nearly 500 species for sale, including lowland gorilla, orang-utan, sable antelope, okapi, Malayan tapir, snow leopard and great red kangaroo, all banned for trade by the International Convention. The going rate for a pair of okapis was 45 million yen $(£ 90,000 ; \$ 158,400)$.

\section{The Greedy Predator}

Eleonora's falcon is a local and endangered species of the eastern Mediterranean, with the peculiarity that it nests in late summer so as to be able to feed its young on the many migrant passerines passing through the area in autumn. One reason why it is endangered and in the Red Data Book may be the fact that fat young chicks are a Cretan delicacy. On a calm Sunday in mid-September 1974 a small armada of boats appeared off some Cretan islands. At least one landed on Paximada and made off with 30-40 chicks, representing some $20-25$ per cent of the island's total chick population. Despite Greek protection laws, this exploitation seems to be on the increase, and may be upsetting the balance which the falcon must have reached with its human predator over the centuries. 


\section{The Two Arguments for Conservation in Africa}

In a paper* entitled 'What is Conservation?', Dr John Hanks, Chief Professional Officer of the Natal Parks, spoke about the arguments to justify wildlife conservation in Africa:

'I believe that there are only two worthwhile arguments to advance in support of wildlife - its ecological value, and its economic value - the others have no place. I have no hesitation in rejecting the aesthetic value of wildlife and the "wilderness concept" as a justification for conservation in Africa. In America and Canada, where there is still land to spare and the population growth rate is very low, the 'wilderness concept' has a very real value; this is not so in Africa, where land is in great demand and the population growth so high ...

'In African countries, the economic value of the wildlife resource is gaining acceptance, and there is no doubt that this could be the most important single contributing factor guaranteeing the promotion and implementation of realistic conservation policies. Tourism is worth nearly US $\$ 100$ million each year in East Africa alone. In addition, hunting, meat production, the sale of skins and ivory and even the sale of live animals for restocking other areas, all generate revenue, and at the same time hundreds of local people are employed in associated industries.

'An even more important justification for conservation comes from the ecological value of wildlife, yet because these benefits are very often indirect and have no economic value, they receive little publicity and are poorly understood. It is important to appreciate that "wildlife" in this context includes all indigenous living organisms in both the plant and animal kingdoms, and their ecological value stems from the fact that man and his domestic species of plants and animals are utterly dependent on the functioning of immense and complex ecological systems that involve these indigenous organisms. These systems include the water, carbon, oxygen and nitrogen cycles. We depend on these cycles for our day-to-day survival. They preserve the atmosphere, help in the disposal of our waste products, and recycle the nutrients used by our food plants. Wildlife species store new genes from which we will be able to produce new domestic animals and crops. Well developed natural plant communities prevent erosion and reduce floods. Soils themselves, something we all take for granted, are the product of the interaction of many living organisms with inorganic particles. Finally, the more species of plants and animals that are present to share the energy flowing through an ecosystem the more stable an ecosystem is likely to be. In other words, the less likely it is that small changes in conditions will cause major disruptions'.

* Presented at the 28th Annual Conservation Conference of the Natural Resources Board, Rhodesia.

\section{Freak Occurrences}

The Center for Short-Lived Phenomena describes itself as 'a global wire service, recording those events which are unusual, unpredictable, pernicious, arbitrary, unforeseeable, and occasionally inexplicable', and its annual reports make gripping reading. The 1974 Annual Report (Center for Short-Lived Phenomena, 185 Alewife Brook Parkway, Cambridge, Mass. 02138, USA; \$10) contains 194 records and 64 photographs of one-off freak occurrences - biological, geophysical, astronomical and industrial; earthquakes, volcanic eruptions, meteorites, whale beachings, sudden animal migrations, plagues, floods and hurricanes; the Canyonville mudslide, the Sumava fireball and the Killarney raining fish. That most of the natural events appear to have only their oddness in common makes the monotony of the industrial pollution section that much more ominous: in one year, they record 83 disasters caused by spills, leaks and discharges of oil, poisonous chemicals and radioactive materials. 